Seyahat ve Otel İşletmeciliği Dergisi/

Journal of Travel and Hospitality Management

14 (3), 2017, 88-109.

Gönderim Tarihi:26.11.2016

Kabul Tarihi:10.05.2017

\title{
Turizm Sektöründe Kadın Girişimciler ve Yöneticiler Açısından Otantik Liderliğin Sosyal Tembellik Üzerindeki Etkileri: Yaşam Tatmininin Düzenleyici Rolü
}

\section{The Effects of Authentic Leadership on Social Loafing for Women Entrepreneurs and Managers in Tourism Industry: The Moderating Role of Life Satisfaction}

Prof. Dr. Mehmet Şerif ŞiMŞEK

Selçuk Üniversitesi

Emekli Öğretim Üyesi

E-posta:simsekserif44@gmail.com

Orcid Id:0000-0002-3539-8296
Prof. Dr. Şevki ÖZGENER*

Nevşehir Hacı Bektaş Veli Üniversitesi

İktisadi ve İdari Bilimler Fakültesi

E-posta: sozgener@nevsehir.edu.tr

Orcid Id:0000-0002-9290-0596

Doç. Dr. İbrahim İLHAN

Nevşehir Hacı Bektaş Veli Üniversitesi

Turizm Fakültesi

E-posta:ibrahim@nevsehir.edu.tr

Orcid Id:0000-0002-6614-9356

$\overline{\mathrm{Oz}}$

Araştırmanın amacı, otantik liderliğin sosyal tembellik üzerindeki etkilerini incelemek ve bu iki değişken arasındaki ilişkide yaşam tatminin düzenleyici rolü oynayıp oynamadığını analiz etmektir. Bu araştırmanın örneklemini Nevşehir ilinde turizm sektöründeki kadın girişimciler ve yöneticiler oluşturmaktadır $(n=110)$. Söz konusu örneklemden elde edilen veriler çoklu regresyon analizi ve düzenleyici değişkenli regresyon analizi yardımıyla analiz edilmiştir. Araştırma bulgularına göre, otantik liderliğin boyutlarından öz farkındalık ve ilişkisel şeffaflığın sosyal tembellik üzerinde negatif etkiye sahip olduğu tespit edilmiştir. Bununla birlikte otantik liderliğin sosyal tembellik üzerinde negatif bir etkiye sahip olduğu belirlenmiştir. Buna karşın, katılımcılar otantik liderlik ve yaşam tatmini etkileşiminin sosyal tembellik üzerinde pozitif etkiye sahip olduğunu ileri sürmüşlerdir. Yani, yaşam tatmininin, otantik liderlik ile sosyal tembellik ilişkisinde düzenleyici rolü oynadığı tespit edilmiştir.

Anahtar Kelimeler: Otantik liderlik, Sosyal tembellik, Yaşam tatmini ve Turizm sektörü

\section{Abstract}

The purpose of this study is to investigate the moderating role of life satisfaction in determining the effects of authentic leadership on social loafing in tourism industry. The sampling consists of women entrepreneurs and managers $(n=110)$ in tourism industry in the Nevşehir Province, Turkey. Data acquired from mentioned research sampling has been analyzed by means of the Multiple Regression Analysis and Moderated Regression Analysis. The findings of the research indicated that the dimensions of self-awareness and relational transparency of authentic leadership had a negative effect on social loafing. Similarly, it stated that authentic leadership had a negative effect on social loafing. Nevertheless, the participants suggested that the interaction of authentic leadership and life satisfaction had a positive effect on social loafing. Namely, life satisfaction moderated the relationship between authentic leadership and social loafing.

Keywords: Authentic leadership, Social loafing, Life satisfaction and Tourism industry.

\section{* Sorumlu Yazar}




\section{Giriş}

Sosyal tembellik, hem küçük gruplarda hem de büyük ölçekli örgütlerde gözlenen verimlilik düşüşü olarak ifade edilen bir olgudur (Hildreth, 2015). Günümüzde örgüt ortamında çalışanların ekip çalışması esnasında sosyal tembellik eğilimi göstermeleri iş dünyasında ve işletmelerde krizlerin ortaya çıkma olasılığını artırmaktadır. Özellikle soyutluk ve düşük görev belirginliği nedeniyle turizm sektöründe ekip çalışmasına dayalı işlerde ve organizasyonlarda çalışanlar arasında sosyal tembellik yaygın bir şekilde görülmektedir. Dolayısıyla sosyal tembelliğin turizm işletmelerinin başarısını negatif yönde etkilediği ifade edilebilir (Luo ve diğ., 2013: 456-457).

Turizm işletmelerinde sosyal tembellik olgusunun gerisinde; motivasyon eksikliği, değerlendirme eksikliği, grup üyelerinin katkılarının belli olmaması durumu, eşit katkı sağlayamama, genel amaç belirleme gibi nedenler yatmaktadır (Özgener ve diğ., 2013: 404). Ayrıca görevi gerçekleştirirken ekipteki kişi sayısının çok fazla olması nedeniyle ortaya çıkan koordinasyon eksikliği, görevin basit ve sıradan algılanması, uygun grup büyüklüğünün belirlenememesi (Kreitner ve Kinicki, 2001: 402), kişinin kaytarma eğilimi göstermesi ve hesap verilebilirlik eksikliği de turizm sektöründe sosyal tembelliğin gerisindeki nedenlerden bazılarıdır (Frash ve diğ., 2004: 58-64). Dolayısıyla performans düşüklüğüne neden olan sosyal tembellik eğilimini azaltmak için turizm sektöründeki işletmeler etkili yöntemler ve yollar aramaktadır. Bu yöntemlerden biri de liderlik tarzı ve liderin tutumu olmaktadır. Özellikle liderlik tarzlarından otantik liderliğin felsefesi itibarıyla sosyal tembellik eğilimini azaltabileceği düşünülmektedir.

Otantik liderlik, lider ve izleyicileri tarafından hem en yüksek düzeyde öz farkındalık ve kendi kendini denetleyen pozitif davranışlarla sonuçlanan, hem de kendi kendini geliştirmeyi teşvik eden pozitif psikolojik beceriler ve son derece gelişmiş örgütsel bağlamdan yararlanan çok boyutlu bir süreç olarak tanımlanabilir (Algera ve Lips-Wiersma, 2012: 120). Otantik liderler, ilişkisel şeffaflığı benimseyerek ideallerini, değerlerini ve standartlarını başkalarına açıklamakta ve izleyicilerin onu doğru tanımasına olanak sağlamaktadır. Bu yaklaşım nedeniyle izleyiciler de onların amaçlarını ve değerlerini benimsediğinden sosyal tembellik eğilimi azalmaktadır. Bu liderler bir model olarak çalışanları ilham ettirmesi ve karar alma sürecinde onların intiyaç duyduğu bilgileri farklı kaynaklardan objektif bir şekilde elde edebilmesine imkan tanıdığı için, hem çalışanların içsel motivasyonu yüksek olmakta, hem de çalışanlar çabalarını artırmaktadır. Daha önemlisi otantik lider güçlü ve zayıf taraflarını bildiğinden ve kendini doğru sunduğundan başkalarını etkilemekte ve onlara etik açıdan güven vermektedir (Müceldili ve diğ, 2013: 674-675; Yeşiltaş ve diğ., 2013: 336-337; Cianci ve diğ., 2014: 583; Hinojosa ve diğ., 2014: 597). Bununla birlikte çalışanlar içselleştirilmiş etik değerleri benimseyerek yöneticinin olmadığı ortamlarda dahi sorumluluktan kaçmamakta ve çabalarını azaltmamaktadır (Walumbwa ve diğ., 2008: 95-96). Bu sebeple otantik liderlik becerisine sahip yöneticilerin ekip çalışmasında sosyal tembellik eğilimini azaltabileceği ileri sürülebilir. Ayrıca otantik liderlik becerilerinin kullanımının yaşam tatmininden bağımsız olamayacağı düşünülmektedir. Bu kapsamda, çalışmada otantik liderlik ile sosyal tembellik arasındaki ilişki ve yaşam tatminin bu ilişkideki düzenleyici etkisi çalışmanın temel sorunsalını oluşturmaktadır.

Yaşam tatmini, bir kişinin genel yaşam kalitesi ile ilgili genel ve sürekli bir değerlendirmedir (Shen ve Huang, 2012: 1285; Ye ve diğ., 2012: 546). Başka bir ifadeyle, yaşam tatmini bireyin iş dışı yaşamı hakkındaki genel duygusal tepkisi olarak tanımlanabilir (Kale, 2013: 122-123). Bireyin yaşam ile ilgili genel tutumunun otantik liderin becerisini kullanmasını olumlu veya olumsuz yönde etkileyebileceği ifade 
edilebilir. Ayrıca yaşam tatmini olgusu temelinde otantik liderlik ile sosyal tembellik ilişkisini ele alan sınırı sayıda çalışmaya rastlanmaktadır. Bu nedenle çalışma örgütsel davranış yazınına teorik ve ampirik olarak katkı sunmayı amaçlamaktadır. Bu bağlamda çalışmanın temel amacı, turizm sektöründeki kadın girişimci ve yöneticiler açısından otantik liderlik ile sosyal tembellik ilişkisini incelemek ve yaşam tatminin bu ilişkide düzenleyici rolü oynayıp oynamadığını ortaya koymaktır.

\section{Literatür Taraması}

Bu kısımda otantik liderlik, sosyal tembellik ve yaşam tatmini değişkenleri kavramsal olarak ele alınmakta ve bu değişkenler ile ilgili araştırma bulgularına yer verilmektedir. Çalışmada turizm sektöründeki kadın girişimci ve yöneticiler açısından otantik liderlik becerilerinin yaşam tatmini bağlamında sosyal tembelliği ne ölçüde ve ne yönde etkileyeceği analiz edilmektedir.

\subsection{Otantik Liderlik}

Turizm sektöründe kadın girişimci ve yöneticiler giderek daha fazla iş yaratmakta ve karar verme mekanizmalarına daha fazla dahil olmaktadır. Çalışanlar kadın liderlerini otantik, gerçekçi ve kararlara katılımcı olarak algıladıkları zaman, işlerine pozitif yaklaşmakta, işe bağlanma yüksek olmakta ve yönetime güven düzeyi yüksek olmaktadır (Wong ve Laschinger, 2012: 948).

Otantik liderlik çalışmaları, daha çok otantik liderliği tanımlama, otantik liderlik yapısını inceleme, diğer liderlik tarzları ile farklı yanlarını ortaya koyma, örgütler açısından pozitif yanlarını ele alma ve otantik liderliği geliştirme yolları üzerine yoğunlaşmıştır (Berkowich, 2014: 245). Bu çalışma ise hizmet sektöründe otantik liderliğin sonuçları üzerine bazı çıkarımlarda bulunmayı amaçlamaktadır.

Yunanca'daki "authento" sözcüğünden türetilen otantiklik kavramı, bireyin kendi etki alanını tayin etmesi olarak ifade edilir (Gardner ve diğ., 2011: 1121). Başka ifadeyle, otantiklik, bireyin içsel düşünce ve fikirleri ile tutarlı bir şekilde kendisi olma durumunu ifade eder (Bolat ve diğ., 2016: 79). Berkowich'e (2014: 246) göre otantiklik, birinin "doğru kendinin farkında olması" demektir. Otantiklik terimi, birinin "kendini bilme"si ya da kişisel deneyimleri temelinde düşünce, duygu, gereksinim, istek, tercih, inanç ve süreçleri sahiplenmesidir. Kısacası otantiklik, birinin kendi doğrularıyla uyumlu hareket etmesi, içsel düşünce ve duygularıyla tutarlı olacak şekilde kendisini ifade etmesidir (Avolio ve Gardner, 2005: 320).

Otantik liderlik teorisi, bireyin bağlamsal etkilerden bağımsız "doğru kendi" ve "kendine karşı dürüst olma" şeklindeki modern psikolojik varsayımlara dayanmaktadır (Berkowich, 2014: 246). Daha doğrusu otantik liderlik düşüncesi pozitif psikolojide köklerini bulmaktadır (Avolio ve Gardner, 2005: 320). Otantik liderliğin, dönüşümcü ve etik liderlik gibi diğer liderlik biçimlerini bütünleştirebilen bir kök yapı olduğu düşünülmektedir (Algera ve Lips-Wiersma, 2012: 119).

Örgütsel davranış alanında otantik liderlik teorisi ve uygulaması üzerine yapılan çalışmalar son otuz yılda büyük bir gelişme göstermiştir (Henderson ve Hoy, 1983; Bhindi ve Duignan, 1997; Begley, 2001; George, 2003; Luthans ve Avolio, 2003; Avolio ve diğ., 2004; Gardner ve Schermerhorn, 2004; Pittinsky ve Tyson, 2005). Otantik liderlik teorisinin üç temel amacı mevcuttur: (1) Otantik liderlik, şirketlerde etik krizler üzerinde yoğunlaşmak suretiyle büyük şirket skandalları ve kötü yönetim uygulamalarının azaltımasına/önlenmesine yardımcı olmak, (2) Etik iklimi teşvik 
edecek, güven bunalımını ortadan kaldıracak, etik ve sosyal olarak sorumlu tarzda işi yürütmeye yardımcı olacak bir etik pusula olmak ve 3) Insanların işlerinde anlam bulmasına yardımcı olmak ve örgüt üyelerinin refahını artırmak (Algera ve LipsWiersma, 2012: 118).

Otantik liderler, kim olduklarını, ne düşündüklerini ve nasıl davrandıklarını bilen, kendi ve başkalarının değerlerinin, etik anlayışlarının, bilgilerinin ve güçlü yanlarının farkında oldukları başkaları tarafından algılanan, faaliyet gösterdikleri bağlamın farkında olan kendine güvenen, umutlu, psikolojik olarak dayanıklı ve yüksek ahlaki karaktere sahip kişilerdir (Gardner ve diğ., 2011: 1122). Otantik liderlerin beş temel özelliği söz konusudur. Bunlar (Avolio ve Gardner, 2005: 321; Harvey ve diğ, 2006: 2);

- Otantik liderler, başkalarının beklentilerine uygun davranışlar sergilemekten ziyade kendilerine karşı dürüst davranırlar.

- $\quad$ Otantik liderler, statü, şöhret ve diğer kişisel kazançları elde etmekten ziyade kişisel inançlarıyla motive olmaktadırlar.

- $\quad$ Otantik liderler, taklitçi değil orijinaldirler; yani kendi kişisel bakış açılarından yola çıkmaktadırlar.

- Otantik liderler, eylemlerini kişisel değerler ve inançlarına dayandırırlar.

- $\quad$ Otantik liderler, otantik olmayan şekilde eyleme geçmesi için güçlü dış baskılar ve teşvikler var olduğunda bile otantik davranışları tercih etme becerisine sahiptirler.

Otantik liderlik; pozitif yönde kendini geliştirmeyi arzu eden izleyicilerle birlikte en yüksek düzeyde öz farkındalığı, içselleştirilmiş etik anlayışını, dengeli bilgi işlemeyi ve ilişkisel şeffaflığı teşvik etmek için hem pozitif psikolojik yetenekler, hem de pozitif etik iklimden yararlanan ve onu teşvik eden lider davranışına ilişkin bir modeldir (Cianci ve diğ., 2014: 582). Başka bir ifadeyle, otantik liderlik, öz farkındalık, dürüstlük, şeffaflık, davranışsal bütünlük ve tutarlılığı vurgulayan pozitif ilişki odaklı liderlik tarzıdır (Laschinger ve diğ., 2012: 1267).

Otantik liderlik, kendini bilme ve başkalarının eğilimlerine yönelik duyarlıığın bir fonksiyonu olup, liderin eylemleriyle sinerjiye yol gösterdiği çok boyutlu bir anlayıştır (Gardner ve diğ., 2011: 1122). Bazı araştırmalarda otantik liderlik modelinin izleyicilerin iş tatmini, örgütsel bağlılık, yaratıcılık, işe katılımı, örgütsel vatandaşlık davranışı, psikolojik iyi olma, iş performansı gibi davranış ve tutumlar üzerinde pozitif bir etkiye sahip olduğu ileri sürülmektedir (Xiong ve Fang, 2014: 921).

Otantik liderliğin boyutları şunlardır (Müceldili ve diğ., 2013: 674-675; Yeşiltaş ve diğ, 2013: 336-337; Cianci ve diğ., 2014: 583; Hinojosa ve diğ., 2014: 597;):

- Öz-farkındalık: Kendini bilme ve dürüst kendini model olarak sunma otantik liderliğin temelini oluşturur. Liderin güçlü ve zayıf yanlarının farkında olması ve bu yönlerini bilerek başkalarını etkileme derecesidir.

- İlişkisel Şeffafık: Lider, ideallerini, değerlerini ve standartlarını başkalarına açıklamalı ve benimsediği değerlerle uyumlu olacak şekilde konuştuğu gibi davranmalıdır. İlişkisel şeffaflık, bireyin doğru düşünce ve duygularını dikkate alarak bilgiyi kabul ederken ve paylaşırken başkalarına dürüst şekilde kendini ve özgünlüğünü sunmayı ifade eder.

- IÇselleştirilmiş Etik Anlayışı: Cazip teklifler, teşvikler gibi dışsal baskılara karşı liderin kararlarını, içselleştirilmiş etik değerler ve standartlara dayandırmasına imkan tanıyan son derece gelişmiş bir etik yapıdır. Bu şekilde etik açıdan rol modeli olan lider, norm olarak kendi etik standartlarını benimseterek izleyicilere yol gösterir. 
- Bilgiyi Dengeli Iş̧leme: Otantik liderlerin, karar alma sürecinde ihtiyaç duyulan bilgileri farklı kaynaklardan objektif bir şekilde elde etmesi, analiz etmesi ve bunu doğru karar verme için kullanması demektir. Karar vermede uygun bilgiyle birlikte başkalarının görüşlerini dikkate alır.

Literatürde otantik liderliğin ahlaki cesaret (Hannah ve diğ., 2011), iş tatmini (Laschinger ve diğ., 2012; Wong ve Laschinger, 2013), duygusal bağlılık (Leroy ve diğ., 2012), iş performansı (Leroy ve diğ., 2012; Wong ve Laschinger, 2013), işgören güveni, işgörenin işe bağlanması (Wang ve Hsieh, 2013), iş yaşam alanları, yöneticiye güven (Wong ve Giallonardo, 2013), personel güçlendirme (Wong ve Laschinger, 2013), özyeterlilik ve iş yaşam alanları (Laschinger ve diğ., 2015) üzerinde pozitif etkiye sahip olduğu ortaya konulmuştur. Buna karşın bazı çalışmalarda ise otantik liderliğin işgücü devri, işyeri kabadayılığı (Laschinger ve diğ., 2012) ve tükenmişlik (Laschinger ve diğ., 2015) üzerinde negatif etkiye sahip olduğu ortaya konmuştur. Ancak otantik liderlik ve boyutları ile sosyal tembellik ilişkisini irdeleyen çalışmalara rastlanmamaktadır.

\subsection{Sosyal Tembellik}

Sosyal tembellik, bireyin bir grupta yaptığı işin miktarının yalnız başına yaptığından daha az olması eğilimini ifade eder (Kugihara, 1999: 517). Başka bir ifadeyle, sosyal tembellik, bireyin grup ortamında kişisel performansının kesin olarak belirlenemediği durumlarda yalnız başına gösterdiği çabadan daha düşük çaba harcama eğilimidir (Klehe ve Anderson, 2007: 251-252). Sosyal psikolojide gruplarda bireyin performansı ölçülürken veya değerlendirilirken açık bir standart olmadığında bireylerin tam olarak çabalarını ortaya koymama eğilimi en yüksek düzeye çıkmaktadır. Karmaşık ve güç görevlerde minimum düzeyde sosyal tembellik eğilimi ortaya çıkarken, kolay ve tekrarlı görevlerde sosyal tembellik eğilimi maksimum düzeydedir (Thompson ve Thornton, 2007: 159-160). Bu yüzden turizm sektöründe rutin işleri yürüten ekiplerde sosyal tembellik eğiliminin daha fazla olduğu düşünülmektedir (Luo ve diğ, 2013; Akgündüz ve diğ., 2015; Genç ve diğ., 2016).

Sosyal tembellik konusunun temelleri bir Fransız ziraat mühendisi olan Max Ringelmann'ın 1913 yılındaki çalışmalarına kadar geriye götürülebilir. Ringelmann çeşitli tarım uygulamalarındaki hayvanların, insanların ve makinaların etkinliğini incelemiş ve üye sayısı arttığı zaman grubun genel performansında bir düşme olduğunu ortaya koymuştur. Bu çalışmaları nedeniyle bu olgu Ringelmann etkisi kavramıyla bilinir olmuştur (Recario ve diğ., 2015: 2). Ringelmann'ın halat çekme deneyinde; kişiler tek başlarına halatı \%100 (63 kg) bir kuvvetle, iki kişilik gruplar 93\% (118 kg) kuvvetle ve 3 kişilik grup halatı \%85 kuvvetle (160 kg) çekmişlerdir. Grubun 8 kişi olması durumunda halatı \%49 (248 kg) kuvvetle çektikleri tespit edilmiştir. Deneyin araştırma bulguları, gruplarda koordinasyon kaybı nedeniyle bireysel çabanın azaldığını ortaya koymuştur (Doğan ve diğ., 2012: 57).

Sosyal tembelliğin var olduğu gruplarda, bireylerin özgür süvari etkisi veya bedavacı etkisi (free rider effect) ve enayi etkisi (sucker effect) gibi iki farklı tutum sergiledikleri ileri sürülmektedir. Özgür süvari etkisi, teknik olarak herhangi bir çaba harcamadığı halde grubun kazancını paylaşan bir bireyin eylemi olarak tanımlanmaktadır (Recario ve diğ., 2015: 2). Bedavacı bireyler, grup görevini gerçekleştirmek için pek çaba sarf etmeyen, fakat çaba sarf eden grup üyeleriyle aynı ödülü alan bireylerdir. Yani bireyin herhangi bir katkıda bulunmadan kollektif üretimden yararlanmasıdır. Kaytaranların veya bedavacıların eksik bıraktığı görevi üstlenen ve dolayısıyla fazladan çaba sarf eden grup üyeleri ise enayi rolünü üstlenmektedir. Bu 
durum ise literatürde enayi etkisi (sucker effect) olarak isimlendirilmektedir (Akgündüz ve diğ., 2015: 517).

Sosyal tembelliğin nedenlerinin tespit edilmesi hizmetler sektörü açısından kritik önem taşımaktadır. Farklı kültürler ve örgütler dikkate alındığında gruplarda sosyal tembelliğin öncülleri; dışsal öncüller (görev belirginliği, algılanan katkı, adalet) ve içsel öncüller (görevin anlamlıığı, görevin önemi, örgütsel bağlılık, işten ayrılma niyeti) olmak üzere iki kategoride ele alınmıştır (Luo ve diğ., 2013: 456-457).

Algılanan görev belirginliği, gözetimcinin bir işte bireysel çabanın farkında olma inancıdır. Görevin belirginliği düşük olduğunda işgörenler, gözetimcinin kendilerinin ne kadar sıkı çalıştıklarını belirlemede güçlük çekeceğini düşündüklerinden sosyal tembellik ortaya çıkmaktadır. Yine içsel motivasyonun yüksek olması durumunda düşük düzeyde sosyal tembellik ortaya çıkarken, dışsal motivasyonun olduğu durumlarda sosyal tembellik yüksek olmaktadır (George, 1992: 192-194). Öte yandan ulusal kültürün de sosyal tembellik üzerinde etkili olduğu gözlenmektedir. Örneğin; Kugihara (1999) tarafından Japonya'da cinsiyet ile sosyal tembellik ilişkisi üzerine yapılan çalışmada grup ortamında erkeklerde sosyal tembellik görüldüğü ancak kadınlarda görülmediği tespiti yapılmıştır.

Soyutluk ve düşük görev belirginliği nedeniyle hizmetler sektöründe sosyal tembellik yaygın görülmektedir. Sosyal tembellik örgüt başarısı üzerinde çeşitli negatif etkilere sahiptir. Birincisi, bireysel çabayı azaltarak bireylerin iş etkinliğini etkilemektedir. Ikincisi işte bireysel çabayı azaltan üyeler başarı için daha düşük beklentilere sahip olabilir. Bu durumda sosyal tembellik grup açısından düşük bağlılıkla sonuçlanmaktadır (Luo ve diğ., 2013: 456-457).

Çin'de otel çalışanları üzerinde yapılan bir çalışmada işlem adaleti ile sosyal tembellik arasında negatif ilişki olduğu tespit edilmiştir (Luo ve diğ, 2013). Buna karşın Akgündüz ve arkadaşlarının (2015) otel işletmelerinde çalışan işgörenlerin sosyal tembellik (kaytarma) davranışlarına işten ayrılma niyeti ve aşırı rol yükü algılarının etkisini belirlemek amacıyla yaptıkları çalışmada, aşırı rol yükünün, zaman yetersizliği algısının ve işten ayrılma niyetinin çalışanların sosyal tembellik davranışını artırdığı ortaya konmuştur.

Kahai ve arkadaşları (2003) etkileşimci liderliğin sosyal tembellik üzerinde pozitif yönlü etkiye sahip olduğunu ortaya koymuşlardır. Bununla birlikte, Safoora ve arkadaşları (2014) tarafından İran'da liderlik tarzı ve örgütsel iklimin sosyal tembellik üzerindeki etkilerini ele alan çalışmada serbest bırakıcı liderlik tarzının sosyal tembellik üzerinde pozitif etkiye sahip olduğu gözlenmiştir. Buna karşın, Lee ve diğerleri (2015) tarafından vergi kurumunda yapılan bir çalışmada vergi mükelleflerinin destekleyici liderlik davranışlarının vergi toplayanların sosyal tembelliğini negatif yönde etkilediği tespit edilmiştir. Ayrıca Byun ve diğerleri (2015) Güney Kore'deki 6 büyük ölçekli işletme çalışanları üzerinde yaptıkları araştırmada etik liderliğin yüksek düzeyinin sosyal tembelliği dolaylı olarak negatif yönde güçlü bir biçimde etkilediği saptanmıştır.

Xiong ve Fang (2014) tarafından Çin şirketlerinde grup düzeyinde işgörenler üzerinde yapılan çalışmada ise otantik liderliğin her bir boyutunun ve bir bütün olarak otantik liderliğin grup performansı ve kolektif etkinlik üzerinde pozitif bir etkiye sahip olduğuna işaret edilmiştir. Bununla birlikte otantik liderliğin izleyicilerin performansı (Wang ve diğ., 2014), grup kaynaşması ve grup özdeşleşmesi (López ve diğ., 2015) üzerinde pozitif etkiye sahip olduğu ortaya konulmuştur. Öte yandan otantik liderliğin boyutlarından ilişkisel şeffaflığın bireye yönelik örgütsel vatandaşıı davranışı ile pozitif 
ilişki içinde olduğu ve ayrıca ilişkisel şeffaflık ve içselleştirilmiş ahlaki anlayış ile örgüte yönelik örgütsel vatandaşlık davranışı arasında pozitif yönlü ilişki olduğu (Valsania ve diğ., 2012) saptanmıştır.

Literatür incelendiğinde sosyal tembellik ile birçok faktörün ilişkisinin analiz edildiği görülmektedir. Buna karşın otantik liderlik ile sosyal tembellik arasındaki ilişkiler henüz belirsizdir. Bu belirsizliği azaltmak için çalışmada otantik liderlik ile sosyal tembellik arasındaki ilişkiler incelenmektedir. Literatürdeki bulgular referans alınarak çalışmada otantik liderlik ve boyutları ile sosyal tembellik ilişkisine dair şu hipotezler geliştirilmiştir:

Hipotez 1: Otantik liderlik, sosyal tembellik üzerinde negatif etkiye sahiptir.

Hipotez 2a): Otantik liderliğin boyutlarından öz farkındalık, sosyal tembellik üzerinde negatif etkiye sahiptir.

2b) Otantik liderliğin boyutlarından ilişkisel şeffaflık, sosyal tembellik üzerinde negatif etkiye sahiptir.

2c) Otantik liderliğin boyutlarından içselleştirilmiş etik anlayışı, sosyal tembellik üzerinde negatif etkiye sahiptir.

2d) Otantik liderliğin boyutlarından dengeli bilgi işleme, sosyal tembellik üzerinde negatif etkiye sahiptir.

\subsection{Yaşam Tatmini}

Illk kez 1961 yılında Neugarten, tarafından ortaya atılan yaşam tatmini kavramı; bir bireyin kendi belirlediği kriterlere uygun bir biçimde tüm yaşamını pozitif değerlendirmesi olarak tanımlanmaktadır (Özer ve Özsoy Karabulut, 2003: 73; Deniz ve diğ., 2012: 430). Yaşam tatmini, bireyin kendine özgü kriterlerine dayalı genel yaşam koşullarının bilişsel değerlendirmesini ölçen çok faktörlü psikolojik iyi olma kavramını kapsar (Moor ve diğ., 2014: 310).

Yaşam tatmini, bireylerin öznel iyi oluşlarına dair bilişsel algı düzeylerini yansıtır (Lee ve diğ., 2015: 4). Yaşam tatminini demografik faktörler, ekonomik faktörler, sosyokültürel faktörler, kişisel faktörler, iş koşulları, örgütsel faktörler ve psikolojik faktörler etkilemektedir (Keser, 2005: 80; Shen ve Huang, 2012: 1285; Kara ve diğ., 2013: 9-11; Güner ve diğ., 2014: 61; Matud ve diğ., 2014: 206). Ancak yaşam tatminini belirleyici ölçütler şunlardır (Özer ve Özsoy Karabulut, 2003: 73):

- Bireyin günlük yaşamdaki etkinliklerden zevk alması,

- Yaşamının bir anlam taşıması, yaşamıyla ilgili amaçlarının olması ve geçmiş yaşamının sorumluluğunu kabul etmesi,

- Yaşamı boyunca öngördüğü amaçlara ulaştığı inancına sahip olması,

- Olumlu bir "ben" imgesine sahip olması ve bireyin zayıflıkları ne olursa olsun, kendini değerli bir varlık olarak kabul edebilmesi,

- Yaşama karşı genelde iyimser bir tutum içinde olması,

- İşyerinde başarılı olması ve işyerinde kişilerarası faaliyetleri etkin yönetmesi.

Yaşam tatminin verimlilik üzerinde etkili olduğu varsayımı yaygın kabul görmektedir. Yaşam tatminin öğrenci performans üzerindeki etkisi üzerinde duran Rode ve arkadaşları (2005) yaşam tatminin öğrencinin akademik başarısı açısından belirleyici olduğunu saptamışlardır. Öte yandan Aggarwal ve O'Brien (2008) grup projelerinde sosyal tembelliğin öğrenci tatmini üzerindeki etkilerini inceledikleri çalışmada sosyal tembellik azaldıkça tatminin azaldığını gözlemişlerdir. Ancak yaşam tatmininin sosyal tembellik üzerindeki etkileri konusunda çalışmalar çok sınırlıdır. 
Son olarak Özdevecioğlu ve Aktaş (2007) turizm işletmelerinde yaptıkları bir araştırmada iş aile çatışması ile yaşam tatmini arasında negatif bir ilişki olduğunu ileri sürmüşlerdir. Yine Çinli otel yöneticileri üzerinde yapılan çalışmada otel yöneticileri açısından iş-aile çatışmasının yaşam tatminini negatif yönde etkilediği tespit edilmiştir (Zhaoa ve diğ., 2011: 469). Çin'de otel çalışanları üzerinde yapılan araştırmada tükenmişliğin boyutlarından duygusal tükenme ile yaşam tatmini arasında negatif ilişki saptanmıştır (Shen ve Huang, 2012).

Otel çalışanları üzerinde yapılan bir çalışmada dönüşümcü liderliğin çalışanların psikolojik iyi oluş durumunu artırılabileceği ve psikolojik iyi oluş durumunun da en önemli bileşenlerinden biri olan yaşam tatminini artırdığı gözlenmiştir (Kara ve diğ., 2013: 9-11). Bununla birlikte, konaklama işletmelerinde yapılan bir çalışmada lider desteğinin yaşam tatmini üzerinde etkili olduğu tespit edilmiştir (Kale, 2015). Öte yandan otel işletmeleri çalışanları açısından örgüte dayalı öz saygınlığın yaşam tatmini üzerinde pozitif etkiye sahip olduğu gözlenmiştir (Lee ve diğ., 2015: 1).

Ayrıca hizmetler sektöründe cinsiyet açısından da yaşam tatmini üzerine yapılmış sınırlı sayıda çalışma mevcuttur. Matud ve diğerleri (2014) tarafından İspanya'da yaşam tatmini ile ilgili yapılan araştırmada, hem erkekler, hem de kadınlar açısından öz saygınlık ve sosyal desteğin yaşam tatminini pozitif yönde etkilediği saptanmıştır. Benzer şekilde, Güner ve diğerleri (2014: 67) tarafından Burdur ilindeki banka çalışanları üzerinde yapılan bir araştırmada erkeklere göre kadınların daha düşük yaşam tatminine sahip olduğu tespit edilmiştir. Yine mesleki stres ve tükenmişlik ile yaşam tatmini arasında negatif yönlü ilişki olduğu saptanmıştır. Öte yandan, İngiltere'de akademisyenler üzerinde yapılan araştırmada iş-aile çatışmasının yaşam tatminini negatif etkilediği ortaya konmuştur (Mustafayeva ve Bayraktaroğlu, 2014). Ancak turizm işletmeciliği literatüründe girişimci ve yönetici kadınlar açısından yaşam tatmini üzerinde sınırlı sayıda çalışma söz konusudur.

Literatürde gerek otantik liderlik ile yaşam tatmini gerekse yaşam tatmini ile sosyal tembellik arasındaki ilişkileri ele alan çalışma sayısı oldukça sınırıdır (Rode ve diğ., 2005; Aggarwal ve O'Brien, 2008). Bu nedenle literatürdeki bazı çalışmalardan (Kara ve diğ., 2013; Brock, 2015; Kale, 2015; Lee ve diğ., 2015: 1) yola çıkarak otantik liderlik ile sosyal tembellik ilişkisinde yaşam tatmininin düzenleyici rolü oynayıp oynamadığına dair ileri sürülen hipotez şu şekildedir:

Hipotez 3: Yaşam tatmini, otantik liderlik ile sosyal tembellik arasındaki negatif ilişkide düzenleyici rolü oynayacaktır.

\section{Araştırmanın Yöntemi}

\subsection{Evren ve Örneklem}

Çalışmanın evrenini, Türkiye'de turizm sektöründe çalışan kadın girişimciler ve yöneticiler oluşturmaktadır. Ancak belirlenmiş olan evrendeki yönetici ve girişimcilere ulaşma olanağının olmaması ve veri toplama sürecinde karşılaşılan maliyet, zaman gibi kısıtlar nedeniyle örneklem yapılması uygun görülmüştür (Altunışık ve diğ., 2007). Bu çalışmanın örneklemini, Nevşehir ilinde turizm sektöründe iş kuran veya yöneten kadın girişimciler ve yöneticiler oluşturmaktadır. Nevşehir ilinde turizm sektöründe çalışan kadın girişimci ve yönetici sayısı tam olarak bilinmediğinden örneklem aşağıdaki formül yardımıyla hesaplanmıştır. \%95 güven düzeyinde;

$$
\mathrm{n}=\mathrm{z}^{2}(\mathrm{pq}) / \mathrm{e}^{2}=(1.96)^{2}(0.5) \cdot(0.5) /(0.05)^{2}=384
$$


Bu çalışmada sektördeki 384 kadın girişimci ve yöneticiye bizzat araştırmacılar tarafından anketler dağıtılmıştır. Ancak araştırmaya konu girişimci ve yönetici kadınlardan elde edilen anket formlarından eksik cevaplanmış ve cevaplanmayan anketler çıkarıldıktan sonra bilimsel olarak analiz tabi tutulabilir toplam 110 anket elde edilmiştir. Yani anketlerin geri dönüş oranı \%28.6 olarak gerçekleşmiş ve bu oranın bilimsel araştırmalarda yüksek olduğu kabul edilmektedir (Laschinger ve diğ., 2015; Keser ve Kocabaş, 2014).

\section{2. Ölçekler}

Bu araştırmada veriler, George (1992) tarafından geliştirilen Sosyal Tembellik Ölçeği; Walumbwa ve diğerleri (2008) tarafından geliştirilen Otantik Liderlik Ölçeği, Diener ve arkadaşları (1985) tarafından tasarlanan Yaşam Tatmini Ölçeği ve katılımcıların demografik özelliklerini ihtiva eden bir soru formu aracılığı (anket) ile toplanmıştır. Araştırmada kullanılan ölçekler aşağıda ayrıntılı olarak izah edilmektedir:

Sosyal Tembellik Ölçeği: Turizm sektöründeki girişimci ve yönetici kadınların sosyal tembellik eğilimlerini ölçmek için George (1992) tarafından geliştirilen Sosyal Tembellik Ölçeği'nden yararlanılmıştır. 5'li likert tipi olan ölçek, 13 ifadeden oluşmaktadır (1=Kesinlikle Katılmıyorum, $5=$ Kesinlikle Katılıyorum). Sosyal tembellik ölçeğinin güvenirlik katsayısı 0.73 olarak saptanmıştır. Nunnally (1978)'e göre bir ölçeğin bilimsel açıdan güvenilir kabul edilebilmesi için Cronbach's Alpha değerinin 0.70 'in üzerinde olması gerekir. Bu nedenle ölçeğin güvenilir olduğu söylenebilir.

Otantik Liderlik Ölçeği: Turizm sektöründeki girişimci ve yönetici kadınların otantik liderlik eğilimlerini ortaya koymak için Walumbwa ve diğerleri (2008) tarafından geliştirilen Otantik Liderlik Ölçeği kullanılmıştır. Bu ölçek 5'li likert olup 16 ifadeden oluşmaktadır (1=Kesinlikle Katılmıyorum; 2= Katılmıyorum; 3= Ne Katılıyorum $\mathrm{Ne}$ Katılmıyorum; 4=Katılıyorum; 5= Kesinlikle Katılıyorum). Otantik liderlik ölçeğinin dört boyutu mevcuttur: Özfarkındalık (4 ifade), ilişkilerde şeffaflık (4 ifade), içselleştirilmiş ahlak anlayışı (4 ifade) ve dengeli bilgi işleme (4 ifade). Bu çalışmada otantik liderlik ölçeğinin güvenilirlik katsayısı (Cronbach's Alpha) 0.86 olarak hesaplanmıştır.

Yaşam Tatmini Ölçeği: İşgörenlerin yaşam tatmini düzeylerinin tespit edilmesi amacıyla Diener ve arkadaşları (1985) tarafından geliştirilen Yaşam Tatmini Ölçeği kullanılmıştır. Yaşam tatmini ölçeği 5 'li likert tipi olup, "Yaşam koşullarım mükemmeldir" gibi 5 ifadeyi intiva etmektedir (1=Kesinlikle katılmıyorum; 5=Kesinlikle katılıyorum). Bu ölçeğin güvenilirliği 0.87 'dir.

Bir ölçüm aracının araştırma konusunu doğru ölçmesi için geçerlilik konusu önem arz etmektedir. Ölçekler hazırlanırken daha önce Türkçe örgütsel davranış yazınında sosyal tembellik ölçeği (Kanten, 2014; Ying ve diğ., 2014), otantik liderlik ölçeği (Tabak ve diğ., 2012) ve yaşam tatmini ölçeği (Yetim, 1991; Taşdelen-Karçkay, 2016) kullanım alanı bulmuş ve Türkçe'ye uyarlanmıştır. Ancak yine de ölçeklerin İngilizce versiyonu daha önce birbirini görmemiş üç örgütsel davranış uzmanı tarafından birbirinden bağımsız olarak Türkçe'ye çevrilmiş ve daha sonra bu ölçeklerin Türkçe ifadelerinin özgün ifadeyi anlam ve içerik yönünden karşılayıp karşılamadığını ortaya koymak için örgütsel davranış ve iş psikolojisi alanında İngiltere'de eğitim görmüş bir uzman tarafından incelenmiştir. Uzmanın görüşü dikkate alınarak ölçeklere son şekil verilmiştir. Mevcut ölçeklerde ifade sayısı ve derecelendirme ölçekleri orijinal ölçekteki gibi bırakılmıştır. Buna ilaveten her bir ölçeğin Türkçe ifadeleri birbirinden bağımsız olarak farklı yerlerdeki üç uzman tarafından tekrar İngilizceye çevrilmiştir. 
Böylece ölçeklerin dil bakımından geçerliliği süreci tamamlanmıştır. Nihai Türkçe ve İngilizce ölçeklerle iki hafta ara ile turizm bölümlerindeki kız öğrenciler üzerinde bir pilot çalışma $(n=30)$ yapılmıştır. Bu pilot çalışmadan sonra iki uygulama arasında sosyal tembellik $(r=0.70)$ otantik liderlik ölçeği $(r=0.74)$ ve yaşam tatmini ölçeği $(r=0.81)$ yüksek düzeyde ilişki saptanmıştır (Doğan, 2015).

\subsection{Araştırma Modeli ve Veri Analizi}

$\mathrm{Bu}$ çalışmanın araştırma modeli, otantik liderlik ve boyutları bağımsız değişken, yaşam tatmini aracı değişken ve sosyal tembellik ise bağımlı değişken kabul edilerek tasarlanmıştır.

\section{Şekil 1: Araştırma Modeli}

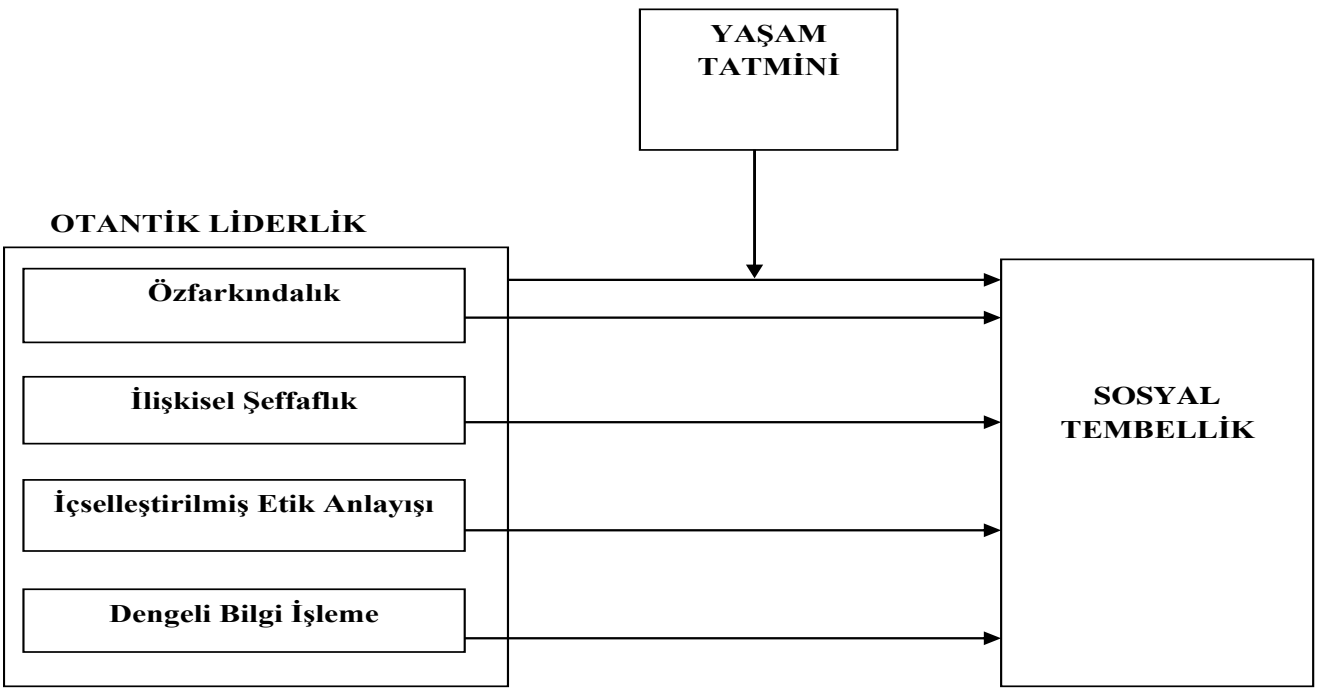

$\mathrm{Bu}$ modeli test etmek için araştırmada değişkenlerle ilgili toplanan veriler, Sample K-S seçimi ile Tek örneklem Kolmogorov-Smirnov testi, doğrulayıcı faktör analizi, pearson korelasyon analizi ve çoklu regresyon analizi yardımıyla analiz edilmiştir. Bununla birlikte otantik liderlik (bağımsız değişken) ile sosyal tembellik (bağımlı değişken) ilişkisinde yaşam tatminin düzenleyici rolü oynayıp oynamadığını ortaya koymak için düzenleyici değişkenli regresyon analizinden yararlanılmıştır.

\section{Bulgular}

\subsection{Demografik Değişkenlere Yönelik Bulgular}

Bu çalışma Nevşehir ilinde turizm sektöründeki kadın girişimci ve yöneticiler üzerinde yapılmıştır. Bu girişimci ve yöneticilerin \%63.6'sı evli ve \%36.4'ü bekârdır. Bu katılımcıların \%14.5'i 25 yaş ve aşağısı grupta, \%29.1'i 25-36 yaş aralığında, \%34.6'sı $36-45$ yaş aralığında, \%18.2'si 46-55 yaş aralığında ve \%3.6'sı 46 yaş ve üzeri grupta yer almaktadır.

Araştırmaya katılanların \%11.8'i ilköğretim, \%20.9'u lise ve dengi okul, \%15.5'i meslek yüksekokulu, \%46.3'ü fakülte ve \%5.5'i lisansüstü eğitim düzeyine sahiptir. Bununla birlikte araştırmaya katılan kadın girişimci ve yöneticilerin \%9.1'i 1 yıldan az, 
\%31.8'i 1-5 yıl arası, \%30'u 6-10 yıl arası ve \%29.1'i 10 yıldan fazla bir iş deneyimine sahiptir.

Araştırmaya katılan kadın girişimcilerin \%34.5’i kendi işini kurduğunu ve \%16.4'ü ailesinin kurduğu işletmeyi yönetmekte olduğunu belirtirken, kadın girişimcilerin \% 49.1 'i turizm sektöründe faaliyet gösteren işletmelerde yönetici pozisyonunda görev yaptığını ifade etmektedir. Bu kadın girişimcilerin \%23'ü iş-aile çatışması yaşadıklarını belirtmişlerdir. Bu girişimcilerin sadece \%8.2'si Türkiye Kadın Girişimcileri Derneği (KAGIDER)'ne üyedir.

\subsection{Hipotezlerin Test Edilmesine Yönelik Bulgular}

Yukarıda belirtilen ölçeklerden oluşan anket yardımıyla elde edilen verilerin geçmişte yapılan çalışmalarda kullanılan yapılara uygunluğunu ve teorik olarak geliştirilen modelin uygunluğunu test etmek için Doğrulayıcı Faktör Analizine intiyaç duyulmuştur. Analize otantik liderlik (16 ifade), yaşam tatmini (5 ifade) ve sosyal tembellik (13 ifade) ile başlanmıştır. Ancak doğrulayıcı faktör analizinde değişkenler ile faktörler arasında bir uyum yani yüksek bir korelasyon olmadığı için otantiktik liderliğin alt boyutlarından Öz-farkındalığa ait S9, İlişkisel şeffaflığa ait S10 ve İçsel etik anlayışına ait S11 ifadeleri ölçekten çıkarılmıştır. Benzer şekilde değişkenler ile faktörler arasında yüksek bir korelasyon olmadığı için Sosyal Tembellik Ölçeğindeki ters kodlu S17, S20, S22, S26, S27 ve S28 ifadeler ölçekten çıkarılmıştır. Kovaryans Matrisi ve Maksimum Benzerlik Tahmini (MLE) kullanılarak yapılan doğrulayıcı faktör analizine göre hesaplanan parametre tahmin değerlerinin pozitif, 0,50 ile 0,99 değerleri arasında olması ve ayrıca teorik değerlerinin üzerinde t değerlerine sahip ve istatistiksel olarak anlamlı olması zorunluluktur (Fornell ve Larcker, 1981).

Tablo 1: Ölçeklere İlişkin Doğrulayıcı Faktör Analizi Sonuçları

\begin{tabular}{|c|c|c|c|c|c|c|c|c|c|c|}
\hline Ölçekler & Boyutlar & $\begin{array}{l}\text { Ifade } \\
\text { Sayısı }\end{array}$ & $\begin{array}{l}\text { Std. } \\
\text { Faktör } \\
\text { Yükleri }\end{array}$ & $x^{2} / d f$ & GF & AGF & CF & RMSEA & BYG & OAV \\
\hline \multirow{2}{*}{$\begin{array}{l}\text { Sosyal } \\
\text { Tembell }\end{array}$} & $\begin{array}{l}\text { Başkalarından } \\
\text { Kaynaklanan } \\
\text { Tembellik }\end{array}$ & 3 & $.60-.85$ & \multirow[b]{2}{*}{1.639} & \multirow[b]{2}{*}{.95} & \multirow[b]{2}{*}{.88} & \multirow[b]{2}{*}{.97} & \multirow[b]{2}{*}{.077} & .77 & .47 \\
\hline & $\begin{array}{l}\text { Sorumlulukların } \\
\text { Belirlenmesinden } \\
\text { Kaynaklanan } \\
\text { Tembellik }\end{array}$ & 4 & $.60-.77$ & & & & & & .76 & .52 \\
\hline $\begin{array}{l}\text { Yaşam } \\
\text { Tatmini }\end{array}$ & Yaşam Tatmini & 5 & $.65-.83$ & 1.052 & .98 & .94 & .99 & .022 & .88 & .59 \\
\hline \multirow{4}{*}{$\begin{array}{l}\text { Otantik } \\
\text { Liderlik }\end{array}$} & Öz farkındalık & 3 & $.68-.84$ & \multirow{4}{*}{1.374} & \multirow{4}{*}{.90} & \multirow{4}{*}{.85} & \multirow{4}{*}{.96} & \multirow{4}{*}{.059} & .80 & .57 \\
\hline & İlişkisel Şeffaflık & 3 & $.67-.76$ & & & & & & .75 & .50 \\
\hline & İçsel Etik Anlayışı & 3 & $.61-.80$ & & & & & & .72 & .47 \\
\hline & $\begin{array}{l}\text { Dengeli } \\
\text { İşleme }\end{array}$ & 4 & $.55-.80$ & & & & & & .77 & .53 \\
\hline
\end{tabular}

Tablo 1'de görüldüğü gibi doğrulayıcı faktör analizi sonucunda sosyal tembellik $\left(\mathrm{x}^{2} / \mathrm{sd}=1,639, \mathrm{RMSEA}=.077, \mathrm{CFI}=.97, \mathrm{GFI}=.95\right.$; $\left.\mathrm{AGFI}=.88\right)$, yaşam tatmini $\left(\mathrm{x}^{2} / \mathrm{sd}=\right.$ $1,052, \mathrm{RMSEA}=.022, \mathrm{CFI}=.99, \mathrm{GFI}=.98 ; \mathrm{AGFI}=.94)$ ve otantik liderlik $\left(\mathrm{x}^{2} / \mathrm{sd}=1,639\right.$, RMSEA $=.059, \mathrm{CFI}=.96, \mathrm{GFI}=.90 ; \mathrm{AGFI}=.85$ ) ölçeklerinin kabul edilebilir uyum iyiliği indeksleri verdiği görülmüştür. Yapılan analiz sonucunda ölçeklere dair Kikare/Serbestlik Derecesi (x2/df) değerlerinin tümü 3.0'ün altında, RMSEA değerleri ise 0.08 'inin altında ve CFI değerlerinin 0,95 'in üzerinde olduğu görülmektedir. Bu uyum iyiliği değerleri, örgütsel davranış yazınında bilimsel olarak kabul edilebilir değerlerdir (Jöreskog ve Sörbom, 1993; Hu ve Bentler, 1998; Hooper ve diğ, 2008; Fornell ve 
Larcker, 1981). Buna ilaveten Tablo 1'de görüldüğü üzere, her üç ölçeğin tüm boyutlarının OAV (AVE) değerinin istenilen minimum düzey olan .50'yi geçmesi ve faktör yüklerinin de önerilen .50 faktör yüküne sahip olması nedeniyle yakınsak geçerliğin sağlandığı belirtilebilir. Ancak örneklemin küçük olması nedeniyle sadece sosyal tembelliğin boyutlarından Başkalarından Kaynaklanan Tembellik ve otantik liderliğin boyutlarından İçsel Etik Anlayışına ilişkin OAV değerlerinde küçük bir ihlal yaşandığı söylenebilir. Bu değerlerin de kabul gördüğü bilimsel çalışmalar mevcuttur (Rhodes and Conner, 2010; Plumed ve diğ., 2013). Son olarak ise Tablo 1'de görüldüğü üzere faktörlere ait Bileşik Yapı Güvenirliği (BYG) değerlerinin iyi düzeyde olduğu belirtilebilir (Hu ve Bentler, 1998; Hooper ve diğ, 2008).

Araştırmada verilerin normal dağılıp dağılmadığını tespit etmek için Sample K-S seçimi ile Tek örneklem Kolmogorov-Smirnov testi yapılmıştır. Bu testin sonuçlarına göre otantik liderlik, yaşam tatmini ve sosyal tembellik değişkenlerine ilişkin $p>0.05$ olduğu için verilerin normal dağılım gösterdiği söylenebilir.

Aşağıda Tablo 2'deki korelasyon analizi sonuçları incelendiğinde otantik liderlik ile sosyal tembellik arasında negatif yönlü ve anlamlı bir ilişki olduğu gözlenmektedir $(r=-0,592 ; p<0.01)$. Benzer şekilde, otantik liderliğin boyutlarından öz farkındalık $(r=-$ $0,532 ; p<0.01)$, ilişkisel şeffaflık $(r=-0,503 ; p<0.01)$, içselleştirilmiş etik anlayışı $(r=-$ $0,391 ; p<0.01)$ ve dengeli bilgi işleme $(r=-0,303 ; p<0.01)$ ile sosyal tembellik arasında negatif yönlü ve anlamlı bir ilişki olduğu saptanmıştır. Son olarak yaşam tatmini ile sosyal tembellik arasında da negatif yönlü ve anlamlı bir ilişki olduğu tespiti yapılmıştır $(r=-0,236 ; p<0.05)$. Değişkenler arasındaki korelasyon ilişkilerinin anlamlı olduğu gözlenmektedir. Bu durum regresyon analizinin yapılabilmesinin ön koşullarından biridir.

Tablo 2: Değişkenler Arasındaki Korelasyon Katsayıları, Tanımlayıcı İstatistikler ve Güvenilirlik Katsayıları

\begin{tabular}{|c|c|c|l|l|l|l|l|l|l|}
\hline Değişkenler & $\begin{array}{c}\text { A. } \\
\text { Ort. }\end{array}$ & $\begin{array}{c}\text { Std. } \\
\text { Sapma }\end{array}$ & $\mathbf{1}$ & $\mathbf{2}$ & $\mathbf{3}$ & $\mathbf{4}$ & $\mathbf{5}$ & $\mathbf{6}$ & $\mathbf{7}$ \\
\hline 1.Öz farkındalık & 3,80 &, 78 & $(0.79)$ & & & & & & \\
\hline 2. Ilişkisel Şeffaflık & 3,86 &, 76 &, $566^{* *}$ & $(0.72)$ & & & & & \\
\hline $\begin{array}{c}\text { 3. Içselleştirilmiş } \\
\text { Etik Anlayışı }\end{array}$ & 3,81 &, 80 &, $401^{* *}$ &, $479^{* *}$ & $(0.75)$ & & & & \\
\hline $\begin{array}{c}\text { 4.Dengeli Bilgi } \\
\text { İşleme }\end{array}$ & 3,69 &, 88 &, $362^{* *}$ &, $655^{* *}$ &, $316^{* *}$ & $(0.80)$ & & & \\
\hline 5.Otantik Liderlik & 3,82 &, 60 &, $775^{* *}$ &, $850^{* *}$ &, $722^{* *}$ &, $719^{* *}$ & $(0.86)$ & & \\
\hline 6.Yaşam Tatmini & 3,26 &, 86 &, $217^{*}$ &, $315^{* *}$ &, 164 &, $204^{*}$ &, $308^{* *}$ & $(0.87)$ & \\
\hline $\begin{array}{c}\text { 7.Sosyal } \\
\text { Tembellik }\end{array}$ & 2,57 &, 53 &,$- 532^{* *}$ &,$- 503^{* *}$ &,$- 391^{* *}$ &,$- 303^{* *}$ &,$- 592^{* *}$ &,$- 236^{*}$ & $(0.73)$ \\
\hline
\end{tabular}

** Korelasyon 0.01 düzeyinde anlamlı (Cift yönlü).

* Korelasyon 0.05 düzeyinde anlamlı (Çift yönlü).

Otantik liderliğin boyutlarının sosyal tembellik üzerindeki etkilerini analiz etmek amacıyla yapılan regresyon analizi bulguları incelendiğinde; modeldeki VIF değerleri 1,341-2,415 arasındadır. Bu değerler en üst sınır olarak kabul edilen 10'dan çok düşüktür. En düşük tolerans değeri ise 0.414 olup, en alt sınır değer olan 0.10 'dan yüksektir. Dolayısıyla çoklu regresyon modelinde çoklu bağıntı sorununa rastlanmamıştır (Auzair, 2011). Bununla birlikte Model l'de Durbin-Watson katsayısı 2 civarında olduğundan otokorelasyon sorunu ile karşılaşılmamıştır (Saeed ve diğ., 2013). 
Tablo 3’te görüldüğü üzere otantik liderliğin boyutlarının (öz farkındalık, ilişkisel şeffaflık, içselleştirilmiş etik anlayışı, dengeli bilgi işleme) bağımsız değişken, sosyal tembelliğin bağımlı değişken olarak girdiği Model I istatistiksel açıdan anlamlıdır $\left(R^{2}=0.358 ; \quad F_{(4-105)}=14.639 ; p<0.01\right)$. Modelde otantik liderliğin boyutları bağımlı değişken olan sosyal tembellikteki varyansın \%35.8'ini açıklamaktadır. Regresyon analizi sonuçlarına göre, otantik liderliğin boyutlarından öz farkındalık $(\beta=-0,337$; $p<0.01)$ ve ilişkisel şeffaflığın $(\beta=-0,273 ; p<0.05)$ sosyal tembellik üzerinde negatif ve anlamlı bir etkiye sahip olduğu ortaya konmuştur. Bu bulgular $\mathbf{H 2 a}$ ve $\mathbf{H 2 b}$ hipotezlerini desteklemektedir. Buna karşın otantik liderliğin boyutlarından içselleştirilmiş etik anlayışının sosyal tembellik üzerinde negatif ama anlamlı olmayan bir etkiye sahip olduğu gözlenmiştir ( $\beta=-0,139 ; p>0.05)$. Öte yandan beklenilen tam aksine otantik liderliğin boyutlarından dengeli bilgi işlemenin sosyal tembellik üzerinde pozitif ama anlamlı olmayan bir etkiye sahip olduğu saptanmıştır $(\beta=0,042 ; p>0.05)$. Bu yüzden bulgular $\mathbf{H 2 c}$ ve $\mathbf{H 2 d}$ hipotezlerini desteklememektedir.

Otantik liderliğin bağımsız değişken ve sosyal tembelliğin bağımlı değişken olarak kabul edildiği Model II de istatistiksel olarak anlamlıdır $\left(R^{2}=0.350 ; F_{(1-}\right.$ $\left.{ }_{108)}=58.188 ; p<0.01\right)$. Bu modelde bağımsız değişken olan otantik liderlik, bağımlı değişken olan sosyal tembellikteki varyansın \%35'ini açıklamaktadır. Modelde otantik liderliğin sosyal tembellik üzerinde negatif ve anlamlı bir etkiye sahip olduğu belirlenmiştir $(\beta=-0,592 ; p<0.01)$. Bu bulgulara göre $\mathbf{H 1}$ hipotezi kabul edilmektedir. Yani kadın girişimci ve yöneticilerde otantik liderlik becerilerinin düzeyi yükseldikçe sosyal tembellik eğilimi düşmektedir.

Tablo 3: Regresyon Analizi Sonuçları

\begin{tabular}{|c|c|c|c|c|c|c|}
\hline & \multicolumn{6}{|c|}{ Bağımlı Değişken: Sosyal Tembellik } \\
\hline & $\begin{array}{l}\text { Standardize } \\
\text { edilmemiş } \beta\end{array}$ & SE & $\begin{array}{l}\text { Standardize } \\
\text { edilmiş } \beta\end{array}$ & t değeri & $\mathbf{R}^{2}$ & $\begin{array}{l}\text { Düzetilmiş } \\
\mathbf{R}^{2}\end{array}$ \\
\hline $\begin{array}{l}\text { Model } 1 \\
F_{(4-05)}=14.639\end{array}$ & & & & & .358 & .334 \\
\hline (Sabit) & 2,580 & 042 & & 61,921 & & \\
\hline Özfarkındalık &,- 231 & ,066 &,- 337 & $-3,492^{* *}$ & & \\
\hline İlişkisel Şeffaflık &,- 193 & ,086 &,- 273 & $-2,248^{*}$ & & \\
\hline $\begin{array}{l}\text { İçselleştirilmiş } \\
\text { Etik Anlayışı }\end{array}$ &,- 092 & ,060 &,- 139 & $-1,534$ & & \\
\hline $\begin{array}{ll}\text { Dengeli } & \text { Bilgi } \\
\text { İşleme } & \\
\end{array}$ & ,025 & ,063 & ,042 & ,403 & & \\
\hline $\begin{array}{l}\text { Model II } \\
F_{(1-08)}=58,188\end{array}$ & & & & & .350 & .344 \\
\hline (Sabit) & 2,580 & ,041 & & 62,418 & & \\
\hline Otantik Liderlik &,- 519 & ,068 &,- 592 & $-7,628^{\star *}$ & & \\
\hline
\end{tabular}

Tablo 4'de bağımsız değişken olan otantik liderlik ve düzenleyici değişken olan yaşam tatmini etkileşiminin sosyal tembellik üzerindeki etkilerine yer verilmiştir. Modelde etkileşim terimi sosyal tembellik üzerinde pozitif ve anlamlı bir etkiye sahiptir $(\beta=0,222 ; p<0.01)$. Yaşam tatmini, iki değişken arasındaki ilişkinin negatif olan yönünü, pozitif yöne çevirmiştir. Böylece $\mathbf{H 3}$ hipotezi desteklenmektedir. Yani yaşam tatmini, otantik liderlik ile sosyal tembellik arasındaki ilişkiyi düzenleyici rol oynamaktadır. Etkileşim terimi ilave olarak sosyal tembellikteki varyansın yüzde 4.2'sini açıklamıştır. 
Tablo 4: Düzenleyici Etkisi

\begin{tabular}{|c|c|c|c|c|}
\hline & $\begin{array}{l}\text { Bağıml Değişken: Sosyal } \\
\text { Tembellik ( } \boldsymbol{\beta})\end{array}$ & $\begin{array}{l}\text { Adjusted } \\
\mathrm{R}^{2}\end{array}$ & $\Delta \mathrm{R}^{2}$ & $\begin{array}{l}\mathrm{F} \\
\text { Change }\end{array}$ \\
\hline $\begin{array}{c}\text { Model 1 } \\
\text { Otantik Liderlik }\end{array}$ & $-.581^{* *}$ & .331 & & $54.524^{* *}$ \\
\hline $\begin{array}{c}\text { Model 2 } \\
\text { Otantik Liderlik } \\
\text { Yaşam Tatmini }\end{array}$ & $-.561^{* *}$ & & & \\
\hline $\begin{array}{c}\text { Model 3 } \\
\text { Etkileşim Etkisi }\end{array}$ & -.065 & .329 & .004 & .612 \\
\hline
\end{tabular}

${ }^{* *} p<.01$; Standardize edilmiş $\beta$ değeri kullanılmıştır.

Regresyon analizi sonuçlarına göre yaşam tatmininin otantik liderlik ile sosyal tembellik arasındaki ilişkide düzenleyici (moderator) role sahip olduğu gözlenmiştir. Şekil 2 bu etkileşimin doğası ve yönünü göstermektedir.

\section{Şekil 2: Otantik Liderlik ve Yaşam Tatmini Etkileşiminin Sosyal Tembellik Üzerindeki Etkisinin Doğası ve Yönü}

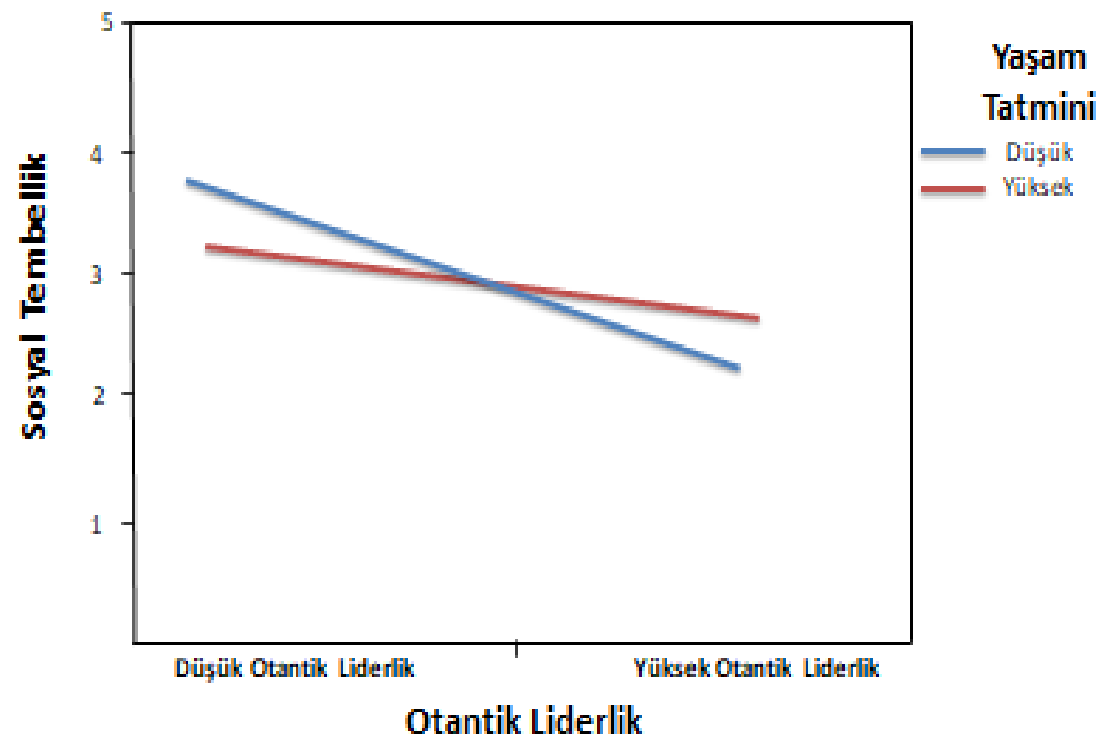

Sosyal tembellikle ilişkili otantik liderlik ve yaşam tatmini etkileşimine dair doğrular, aynı zamanda bir düzenleyici etkiyi göstermektedir. Yüksek yaşam tatminine sahip bireyler, düşük otantik liderlik koşulları altında daha yüksek sosyal tembellik eğilimi göstermektedir. Buna karşın, düşük yaşam tatminine sahip bireyler, yüksek otantik liderlik koşulları altında daha düşük sosyal tembellik eğilimi göstermektedir.

\section{Sonuç ve Öneriler}

Turizm sektöründeki girişimci ve yönetici kadınlar açısından otantik liderliği ele alan çalışmalar sınırlı sayıdadır. Otantik liderlik; lider ile izleyiciler arasında pozitif yönlü bir ilişki gelişmesini sağlamaya dayalı olarak karşılıklı öz bilinç ve öz disiplinin oluşmasını ve böylece pozitif yönde bir kişisel gelişimin önünü açan bir liderlik sürecidir (Keser ve Kocabaş, 2014: 2). Otantik liderler, kendi düşünceleri, davranışları ve diğerleri tarafından nasıl algılandıklarının farkında olan, kendilerinin ve diğerlerinin değerlerini, bilgilerini ve güçlü yanlarını bilen; kendine güvenen, umutlu, iyimser, sorunların hızlı bir biçimde üstesinden gelen ahlaklı bireylerdir (Kesken ve Ayyıldız, 2008: 737). Sosyal 
tembellik ise bireyin grupla birlikte çalışırken, yalnız başına çalışırken sarf ettiği çabadan daha az çaba sarf etme eğilimidir. Özellikle turizm işletmeleri yönetici ve çalışanları arasında aşırı rol yükü, yüksek işten ayrılma niyeti, zamanın yetersizliği gibi nedenler sosyal tembelliği artırmaktadır (Akgündüz ve diğ., 2014: 517-531). Bununla birlikte sosyal tembellik eğiliminin, bir bireyin kendi belirlediği kriterlere göre tüm yaşamını pozitif değerlendirmesi olarak tanımlanan yaşam tatmininden etkilendiği yadsınamaz bir gerçektir (Yerlisu Lapa ve diğ., 2012: 54). Çünkü bireyler iş ortamlarının dışındaki olaylar ve durumlardan etkilenmektedir. Aynı zamanda iş bir bireyin yaşamının önemli bir parçası olduğundan, sosyal tembellik ile yaşam tatmini arasındaki ilişkiyi de ortaya koymak önemlidir (Aşan ve Erenler, 2008: 207). Bu etkinin otantik liderlik becerileri ile ilişkili olarak ele alınması ve olumsuz sonuçlarının en düşük seviyeye indirilmesi oldukça önem arz etmektedir.

Örgütsel davranış araştırmaları, turizm işletmelerinde otantik liderlik niteliklerini iş ortamına daha etkin şekilde yansıtabilen girişimci ve yöneticilerin sosyal tembelliği azaltabileceğini göstermektedir (Xiong ve Fang, 2014; Wang ve diğ., 2014). Otantik liderlik, sosyal tembellik ve yaşam tatminin çeşitli değişkenlerle ilişkisi ele alınmış olmasına rağmen, otantik liderlik ile sosyal tembellik ilişkisinde yaşam tatminin düzenleyici rolünü inceleyen çalışma sayısı henüz azdır. Bu çalışmanın diğer çalışmalardan farkı, otantik liderliğin sosyal tembellik üzerindeki etkilerinin yanı sıra bu iki değişken arasındaki ilişkide yaşam tatminin düzenleyici rolü oynayıp oynamadığını incelemesidir.

Regresyon analizi sonuçlarına göre, otantik liderliğin boyutlarından öz farkındalık ve ilişkisel şeffaflığın sosyal tembellik üzerinde negatif ve anlamlı bir etkiye sahip olduğu tespit edilmiştir. Buna karşın otantik liderliğin boyutlarından içselleştirilmiş etik anlayışının ve dengeli bilgi işlemenin sosyal tembellik üzerinde anlamlı olmayan bir etkiye sahip olduğu gözlenmiştir.

Yine otantik liderlik algısının sosyal tembellik üzerinde negatif ve anlamlı bir etkiye sahip olduğu tespiti yapılmıştır. Lee ve diğerleri (2015) yaptıkları çalışmada destekleyici liderlik davranışlarının sosyal tembelliği negatif yönde etkilediğini ortaya koymuştur. Bu tespit, araştırmada otantik liderliğin sosyal tembellik üzerinde negatif etkiye sahip olduğuna dair bulgu ile paralellik göstermektedir. Yine Laschinger ve arkadaşları (2012) yaptıkları çalışmalarda otantik liderliğin iş gücü devri ve işyeri kabadayılığı üzerinde negatif etkiye sahip olduğunu ileri sürmüşlerdir. Benzer bakış açısıyla değerlendirildiğinde, söz konusu çalışmanın bulguları, bu araştırmadaki otantik liderliğin sosyal tembellik üzerinde negatif etkiye sahip olduğu fikrini dolaylı olarak destekleyici niteliktedir.

Ayrıca araştırmanın bulguları, yaşam tatminin, otantik liderlik ile sosyal tembellik arasındaki ilişkide düzenleyici rolü oynadığını ortaya koymuştur. Yani yüksek yaşam tatminine sahip bireyler, düşük otantik liderlik koşulları altında daha yüksek sosyal tembellik eğilimi göstermiştir. Buna karşın, düşük yaşam tatminine sahip bireyler, yüksek otantik liderlik koşulları altında daha düşük sosyal tembellik eğilimi sergilemiştir. Örgütsel davranış yazınında yaşam tatminin, liderlik tarzları ve sosyal tembellik üzerindeki etkilerine dair çalışmalara rastlanmamıştır. Sadece turizm sektöründe liderliğin ve lider desteğinin yaşam tatminini artırdığına dair bazı çalışmalar mevcuttur (Kara ve diğ., 2013: 9-11 ve Kale, 2015). Bu nedenle örgütsel davranış yazınında sadece otantik liderlik ile sosyal tembellik ilişkisine sınırlı düzeyde odaklanılmış olması ve düzenleyici değişken etkisinin incelenmemesi önemli bir eksiklik olarak görülebilir. Bu alandaki bilgi eksikliğini giderecek olan çalışma, otantik 
liderlik ile sosyal tembellik ilişkisinde yaşam tatminin düzenleyici rolü oynadığına dair ampirik bulgular sunmaktadır.

Bu çalışmada turizm sektöründeki kadın girişimci ve yöneticiler arasında sosyal tembellik eğiliminin orta düzeyde olduğu saptanmıştır. Bu bulgu dikkate alındığında sosyal tembelliği önlemek için iki öneri sunulabilir:

-Yüksek yaşam tatminine sahip kadın girişimcilerin ve yöneticilerin sosyal tembellik eğilimlerini azaltmak için otantik liderlik becerilerinin geliştirilmesi çözüm olabilir.

-Düşük yaşam tatminin sahip kadın girişimcilerin ve yöneticilerin sosyal tembellik eğilimlerini azaltmak için otantik liderlik becerilerini geliştirmekten ziyade kişisel ilişkiler yaratma, görevleri tanımlama, kuralları belirleme, başarıya önem verme, üst nitelikli yardım gibi alternatif yöntemler önerilebilir.

Her sosyal araştırma gibi bu araştırmanın bazı sınırlılıkları söz konusudur. Birincisi; bu araştırmada kullanılan sosyal tembellik ölçeğinin güvenilirliği yüksek olsa da bu ölçeğin geçerliliğinin test edilmesi için farklı ortamlarda ve sektörlerde yeni araştırmalara gereksinim duyulmaktadır. Íkincisi, turizm sektöründeki sınırlı sayıdaki girişimci ve yöneticinin anket sorularını cevaplandırmak için yeterli zaman ayırmamaları olabilir. Üçüncüsü, küçük bir örneklem üzerinde yapılan araştırmanın bulgularını, turizm sektöründeki tüm girişimci ve yönetici kadınlar açısından genellemek doğru bir yaklaşım olarak kabul görmeyebilir.

$\mathrm{Bu}$ çalışmada turizm sektöründeki kadın girişimciler ve yöneticiler açısından otantik liderlik ile sosyal tembellik ilişkisinde yaşam tatminin düzenleyici rolü irdelenmiştir. Türkçe örgütsel davranış yazınında farklı örgütsel ortamlarda, farklı coğrafi bölgelerde ve farklı ulusal kültürlerde cinsiyet açısından otantik liderlik ile sosyal tembellik ilişkisi incelenmeyi beklemektedir. Bununla birlikte gelecekte araştırma yapacaklara turizm sektöründeki kadın girişimciler açısından otantik liderlik ile koridor prensibi ilişkisinde örgütsel adaletin aracı rolüne dair saha araştırması yapmaları tavsiye edilebilir.

\section{Kaynakça}

Aggarwal, P. ve O'Brien, C. L. (2008), 'Social Loafing on Group Projects: Structural Antecedents and Effect on Student Satisfaction', Journal of Marketing Education, 30 (3), ss.255-264.

Akgündüz, Y., Akdağ, G., Güler, O. ve Sünnetçioğlu, S. (2015), 'İşten Ayrılma Niyeti ve Aşırı Rol Yükünün Otel Çalışanlarının Sosyal Aylaklık Davranışlarına Etkisi' Dokuz Eylül Üniversitesi Sosyal Bilimler Enstitüsü Dergisi, 16 (4), ss.515-536.

Algera, P. M. ve Lips-Wiersma, M. (2012), 'Radical Authentic Leadership: Co-Creating The Conditions under Which All Members of The Organization Can Be Authentic', The Leadership Quarterly, 23, ss.118-131.

Altunışık, R., Coşkun, R., Bayraktaroğlu, S. ve Yıldırım, E. (2007), Sosyal Bilimlerde Araştırma Yöntemleri, 5.Baskı, Sakarya: Sakarya Yayıncılık.

Aşan, Ö. ve Erenler, E. (2008), 'İ̧̧ Tatmini ve Yaşam Tatmini İlişkisi' Süleyman Demirel Üniversitesi Iktisadi ve İdari Bilimler Fakültesi Dergisi, 13 (2), ss.203-216.

Auzair, S. M. (2011), 'The Effect of Business Strategy and External Environment on Management Control Systems: A Study of Malaysian Hotels', International Journal of Business and Social Science, 2 (13), ss.236-244.

Avolio, B. J. ve Gardner, W. L. (2005), 'Authentic Leadership Development: Getting to The Root of Positive Forms of Leadership', The Leadership Quarterly 16, ss.315-338. 
Avolio, B. J., Luthans, F. ve Walumbwa, F. O. (2004), Authentic Leadership: TheoryBuilding for Veritable Sustained Performance, Working Paper, Lincoln: Gallup Leadership Institute, University of Nebraska-Lincoln.

Begley, P. T. (2001), 'In Pursuit of Authentic School Leadership Practices', International Journal of Leadership in Education, 4, ss.353-365.

Berkowich, I. (2014), 'Between Person and Person: Dialogical Pedagogy in Authentic Leadership Development', Academy of Management Learning \& Education, 13 (2), ss.245-264.

Bhindi, N., ve Duignan, P. (1997), 'Leadership for A New Century: Authenticity, Intentionality, Spirituality, and Sensibility', Educational Management and Administration, 25(2), ss.117-132.

Bolat, T., Bolat, O. İ. ve Yüksel, M. (2016), 'Hizmetkar Liderlik ve Psikolojik Güçlendirme İlişkisi: Örgüt Kültürünün Düzenleyici Etkisi' Balıkesir Üniversitesi Sosyal Bilimler Enstitüsü Dergisi, 19 (36-1), IïBF - 10. Yıl Özel Sayısı, ss.75-104.

Brock, R. L., Kochanska, O'hara, M. W. ve Grekin, R. S. (2015), 'Life Satisfaction Moderates the Effectiveness of a Play-Based Parenting Intervention in LowIncome Mothers and Toddlers', J Abnorm Chil Psychol, 43(7), ss.1283-1294.

Byun, G. Karau, S. ve Lee, S. (2015), 'A Three-Level Examination of the Cascading Effect of Ethical Leadership on Employee Outcomes', Academy of Management Proceedings, January 2015, ss.17419.

Cianci, A. M., Hannah, S. T., Roberts, R. P. ve Tsakumis, G. T. (2014), 'The Effects of Authentic Leadership on Followers' Ethical Decision-Making in The Face of Temptation: An Experimental Study', The Leadership Quarterly, 25, ss.581-594.

Deniz, M. E., Arslan, C., Özyeşil, Z. ve İzmirli, M. (2012), 'Öz-Anlayış, Yaşam Doyumu, Negatif ve Pozitif Duygu: Türk ve Diğer Ülke Üniversite Öğrencileri Arasında Bir Karşılaştırma' Mehmet Akif Ersoy Üniversitesi Eğitim Fakültesi Dergisi, 12 (23), ss.428-446.

Doğan, A., Bozkurt, S. ve Demir, R. (2012), 'Sosyal Kaytarma Davranışı İle Algılanan Görev Görünürlüğü Arasındaki İlişkinin İncelenmesine Yönelik Bir Araştırma' SÜ IiBF Sosyal ve Ekonomik Araştırmalar Dergisi, 24, ss.53-79.

Doğan, U. (2015), 'Öğrenci Bireysel Sorumluluk Ölçeği-10'un Türkçe Formunun Geçerlilik ve Güvenirlik Çalışması' Trakya Üniversitesi Sosyal Bilimler Dergisi, 17 (1), ss.163-170.

Frash, R. E., Kline, S. ve Stahura, J. M. (2004), 'Mitigating Social Loafing in TeamBased Learning', Journal of Teaching in Travel \& Tourism, 3(4), ss.57-77.

Fornell, C., ve Larcker, D. F. (1981), 'Evaluating Structural Equation Models with Unobservable Variables and Measurement Error', Journal of Marketing Research, 18(1), ss.39-50.

Gardner, W. L. ve Schermerhorn, J. R. Jr. (2004), 'Unleashing Individual Potential: Performance Gains Through Positive Organizational Behavior and Authentic Leadership', Organizational Dynamics, 33, ss.270-281.

Gardner, W. L., Cogliser, C. C., Davis, K. M. ve Dickens, M. P. (2011), 'Authentic Leadership: A Review of The Literature and Research Agenda', The Leadership Quarterly, 22, ss.1120-1145.

Genç, V., Gülertekin Genç, S. ve Kulakoğlu Dilek, N. (2016), 'Otel İşletmelerinde Öz Benlik, Sosyal Kaytarma ve İşe Geç Kalma Tutumu Arasındaki İlişkinin Belirlenmesi: Batman İli Şehir Merkezindeki Otel Çalışanları Örneği', 17.Ulusal Turizm Kongresi, ss.1529-1540, Bodrum-Muğla: Detay Yayıncılık.

George, J. M. (1992), 'Extrinsic and Intrinsic Origins of Perceived Social Loafing in Organizations', Academy of Management Journal, 35 (1), ss.191-202.

George, W. (2003), Authentic Leadership: Rediscovering The Secrets to Creating Lasting Value, San Francisco: Jossey-Bass. 
Güner, F., Çiçek, H. ve Can, A. (2014), 'Banka Çalışanlarının Mesleki Stres ve Tükenmişlik Düzeylerinin İş Doyumu ve Yaşam Doyumu Düzeyleri İle İlişkisi' Uluslararası Alanya İşletme Fakültesi Dergisi, 6 (3), ss.59-76.

Hannah, S. T., Avolio, B. J. ve Walumbwa, F. O. (2011), 'Relationships between Authentic Leadership, Moral Courage, and Ethical and Pro-Social Behaviors', Business Ethics Quarterly 21 (4), ss.555-578.

Harvey, P., Martinko, M. J. ve Gardner, W. L. (2006), 'Promoting Authentic Behavior in Organizations: An Attributional Perspective', Journal of Leadership and Organizational Studies, 12 (3), ss.1-11.

Henderson, J. E. ve Hoy, W. K. (1983), 'Leader Authenticity: The Development and Test of An Operational Measure', Educational and Psychological Research, 3(2), ss.63-75.

Hildreth, R. (2015), 'Strategies for Leaders to Counter Social Loafing Through The Use of Organizati Harvey onal Citizenship Behavior: A Literature Review', The Compass, 1 (2), Article 9. Available at: http://scholarworks.arcadia.edu/ thecompass/vol1/iss2/9 (Erişim tarihi: 20.09.2015).

Hinojosa, A. S., McCauley, K. D., Randolph-Seng, B. ve Gardner, W. L. (2014), 'Leader and Follower Attachment Styles: Implications for Authentic LeaderFollower Relationships', The Leadership Quarterly, 25, ss.595-610.

Hooper, D., Coughlan, J. ve Mullen, M. R. (2008), 'Structural Equation Modelling: Guidelines for Determining Model Fit', Electronic Journal of Business Research Methods, 6 (1), ss.53-60.

Hu, L. ve Bentler, P. M. (1998), 'Fit Indices in Covariance Structure Modeling: Sensitivity to Underparameterized Model Misspecification', Psychological Methods 3 (4), ss.424-453.

Jöreskog, K.G. ve Sörbom, D. (1993), LISREL 8 [Computer software], Chicago, IL: Scientific Software International, Inc.

Kahai, S. S., Sosik, J. J. ve Avolio, B. J. (2003), 'Effects of Leadership Style, Anonymity, and Rewards on Creativity-Relevant Processes and Outcomes in An Electronic Meeting System Context', The Leadership Quarterly, 14, ss.499-524.

Kale, E. (2013), 'Konaklama İşletmelerinde Öz Uyumun İş Performansına Etkisi: Yaşam Doyumunun Aracı Rolü' Yönetim Bilimleri Dergisi, 11 (21), ss.117-133.

Kale, E. (2015), 'Lider Desteği ve İş Arkadaşları Desteğinin İş Performansı Üzerine Etkileri: İş Tatmini ve Yaşam Tatmininin Aracı Rolü' Uluslararası İktisadi ve Idari Incelemeler Dergisi, 7(14), ss.103-119.

Kanten, P. (2014), 'İşyeri Nezaketsizliğinin Sosyal Kaytarma Davranışı ve İşten Ayrılma Niyeti Üzerindeki Etkisinde Duygusal Tükenmenin Aracılık Rolü' Aksaray Üniversitesi Iktisadi ve Idari Bilimler Fakültesi Dergisi, 6(1), ss.11-26.

Kara, D., Uysal, M., Sirgy, M. J. ve Lee, G. (2013), 'The Effects of Leadership Style on Employee Well-being in Hospitality', International Journal of Hospitality Management, 34, ss.9-18.

Keser, A. (2005), 'İş Doyumu ve Yaşam Doyumu İlişkisi: Otomotiv Sektöründe Bir Uygulama' Çalışma ve Toplum, 4, ss.77-96.

Keser, S. ve Kocabaş, İ. (2014), 'ỉlköğretim Okulu Yöneticilerinin Otantik Liderlik ve Psikolojik Sermaye Özelliklerinin Karşılaştırılması' Kuram ve Uygulamada Eğitim Yönetimi, 20(1), ss.1-22.

Kesken, J. ve Ayyıldız, N. A. (2008), 'Liderlik Yaklaşımlarında Yeni Perspektifler: Pozitif ve Otantik Liderlik' Ege Akademik Bakış, 8(2), ss.729-754.

Klehe, U. ve Anderson, N. (2007), 'The Moderating Influence of Personality and Culture on Social Loafing in Typical versus Maximum Performance Situations', International Journal of Selection and Assessment, 15 (2), ss.250-262.

Kreitner, R. ve Kinicki, A. (2001), Organizational Behavior, Fifth Edition, New York: McGraw-Hill Companies, Inc. 
Kugihara, N. (1999), 'Gender and Social Loafing in Japan', The Journal of Social Pscyhology, 139 (4), ss.516-526.

Laschinger, H. K. S., Borgogni, L., Consiglio, C. ve Read, E. (2015), 'The Effects of Authentic Leadership, Six Areas of Worklife, and Occupational Coping SelfEfficacy on New Graduate Nurses' Burnout and Mental Health: A CrossSectional Study', International Journal of Nursing Studies, 52, ss.1080-1089.

Laschinger, H. K. S., Wong, C. A. ve Grau. A. L. (2012), 'The Influence of Authentic Leadership on Newly Graduated Nurses' Experiences of Workplace Bullying, Burnout and Retention Outcomes: A Cross-Sectional Study', International Journal of Nursing Studies, 49, ss.1266-1276.

Lee, K., Choo, S. ve Hyun, S. S. (2015), 'Effects of Recovery Experiences on Hotel Employees' Subjectivewell-Being', International Journal of Hospitality Management, 52, ss.1-12.

Lee, P., Chen, C. ve Liou, K. T. (2015), 'Using Citizens' Leadership Behaviors to Enhance Worker Motivation: Reducing Perceived Social Loafing in a Coproductive Tax Service Program', Public Performance \& Management Review, 39(1), ss.172-197.

Leroy, H., Palanski, M. E. ve Simons, T. (2012), 'Authentic Leadership and Behavioral Integrity as Drivers of Follower Commitment and Performance', Journal of Business Ethics, 107, ss.255-264.

López, C. G., Alonso, F. M,, Morales, M. M. ve León, J. A. M. (2015), 'Authentic Leadership, Group Cohesion and Group Identification in Security and Emergency Teams', Psicothema, 27 (1), ss.59-64.

Luo, Z., Qu, H. ve Marnburg, E. (2013), 'Justice Perceptions and Drives of Hotel Employee Social Loafing Behavior', International Journal of Hospitality Management, 33, ss.456-464.

Luthans, F. ve Avolio, B. J. (2003), 'Authentic Leadership Development'. İcinde K. S. Cameron, J. E. Dutton, \& R. E. Quinn (Editörler), Positive Organizational Scholarship: Foundations of A New Discipline, ss.241-261, San Francisco: Barrett-Koehler.

Matud, M. P., Bethencourt, J. M. ve Ibáñez, I. (2014), 'Relevance of Gender Roles in Life Satisfaction in Adult People', Personality and Individual Differences, 70, ss.206-211.

Moor, I., Lampert, T., Rathmann, K., Kuntz, B., Kolip, P., Spallek, J. ve Richter, M. (2014), 'Explaining Educational Inequalities in Adolescent Life Satisfaction: Do Health Behaviour and Gender Matter?', Int J Public Health, 59, ss.309-317.

Mustafayeva, L. ve Bayraktaroğlu, S. (2014), 'İş-Aile Çatışmaları ve Yaşam Tatmini Arasındaki İlişki: Türkiye ve İngiltere'deki Akademisyenlerin Karşılaştırılması' İşletme Bilimi Dergisi, 2 (1), ss.127-145.

Müceldili, B., Turan, H. ve Erdil, O. (2013), 'The Influence of Authentic Leadership on Creativity and Innovativeness', Procedia - Social and Behavioral Sciences, 99, ss.673-681.

Nunnaly, J. C. (1978), Psychometric theory, 2nd edn. New York: McGraw-Hill.

Özdevecioğlu, M. ve Ataş, A. (2007), 'Kariyer Bağlıı̆̆ı, Mesleki Bağlılık ve Örgütsel Bağlıı̆ıı Yaşam Tatmini Üzerindeki Etkisi: İş-Aile Çatışmasının Rolü’ Erciyes Üniversitesi İktisadi ve Idari Bilimler Fakültesi Dergisi, 28, ss.1-20.

Özer, M. ve Özsoy Karabulut, Ö. (2003), 'Yaşlılarda Yaşam Doyumu' Geriatri, 6 (2), ss.72-74.

Özgener, Ş., Demirtaş, Ö. ve Ulu, S. (2013), 'Kişi-Çevre Uyumu ile Sosyal Tembellik İlişkisinde Pozitif Psikolojik Sermayenin Aracı Rolü', 1.Örgütsel Davranış Kongresi, ss.404-412, Sakarya: Sakarya Üniversitesi İşletme Fakültesi.

Pittinsky, T. ve Tyson, C. J. (2005), 'Leader Authenticity Markers: Findings From A Study of Perceptions of African American Political Leaders', İçinde W. L. 
Gardner, B. J. Avolio, \& F. O. Walumbwa (Editörler) Authentic Leadership Theory and Practice: Origins, Effects and Development, ss. 253-280, Oxford, UK: Elsevier Science.

Plumed, A. B. G., Prado-Gascó, V. J., Badenes, L. V., López, A. O. ve Barrón, R. G. (2013), 'The MOOD Questionnaire: Adaptation and Validation of the Spanish Version', Psicothema, 25 (2), ss.252-257.

Recario, R. N.C., de Robles, M. B. B., Bautista, K. E. P. ve Pabico, J. P. (2015), Social Loafing Among Members of Undergraduate Software Engineering Groups: Persistence of Perception Seven Years After, Institute of Computer Science, University of the Philippines Los Banos, CoRR, 17 September 2015.

Rhodes, R. E. ve Conner, M. (2010), 'Comparison of Behavioral Belief Structures in the Physical Activity Domain', Journal of Applied Social Psychology, 40(8), ss.2105-2120.

Rode, J. C., Arthaud-Day, M. L., Mooney, C. H., Near, J. P., Baldwin, T. T., Bommer, W. H. ve Rubin, R. S. (2005), 'Life Satisfaction and Student Performance', Academy of Management Learning \& Education, 4 (4), ss.421- 433.

Saeed, R., Shakeel, M. ve Lodhi, R. N. (2013), 'Ethical Behavior and Employees Job Performance in Education Sector of Pakistan', Middle-East Journal of Scientific Research, 18 (4), ss.524-529.

Safoora, F., Hamid, A. S., ve Mohsen, G. (2014), 'A Study of the Relationship between Leadership Styles, Organizational Climate and Social Loafing (case study of employees in Golestan Company, Iran)', International Journal of Research in Organizational Behavior and Human Resource Management, 2 (4), ss.145-151.

Shen, H. ve Huang, C. (2012), 'Domestic Migrant Workers in China's Hotel Industry: An Exploratory Study of Their Life Satisfaction and Job Burnout', International Journal of Hospitality Management, 31, ss.1283-1291.

Tabak, A., Polat, M., Coşar, S. ve Türköz, T. (2012), 'Otantik Liderlik Ölçeği: Güvenirlik ve Geçerlik Çalışması' Iş, güç Endüstri İlişkileri ve Insan Kaynakları Dergisi, 14(4), ss.89-106.

Taşdelen-Karçkay, A. (2016), 'Family Life Satisfaction Scale-Turkish Version: Psychometric Evaluation', Social Behavior and Personality, 44(4), ss. 631-640.

Thompson, B. ve Thornton, B. (2007), 'Exploring Mental-State Reasoning as a SocialCognitive Mechanism for Social Loafing in Children', The Journal of Social Psychology, 147 (2), ss.159-174.

Valsania, S. E., León, J. A. M., Alonso, F. M. ve Cantisano, G. T. (2012), 'Authentic Leadership and Its Effect on Employees' Organizational Citizenship Behaviours', Psicothetna, 24 (4), ss. 561-566.

Walumbwa, F. O., Avolio, B. J. Gardner, W. L., Wernsing, T. S. ve Peterson, S. J. (2008), 'Authentic Leadership: Development and Validation of a Theory-Based Measure', Journal of Management, 34:1, ss.89-126.

Wang, D-S. ve Hsieh, C-C. (2013), 'The Effect of Authentic Leadership on Employee Trust and Employee Engagement', Social Behavior and Personality, 41(4), ss.613-624.

Wang, H., Sui, Y., Luthans, F., Wang, D. ve Wu, Y. (2014), 'Impact of Authentic Leadership on Performance: Role of Followers' Positive Psychological Capital and Relational Processes', Journal of Organizational Behavior, 35, ss.5-21.

Wong, C. A. ve Laschinger, H. K.S. (2012), 'Authentic Leadership, Performance, and Job Satisfaction: The Mediating Role of Empowerment', Journal of Advanced Nursing, 69 (4), ss.947-959.

Wong, C. A. ve Giallonardo, L. M. (2013), 'Authentic Leadership and Nurse-Assessed Adverse Patient Outcomes', Journal of Nursing Management, 21, ss.740-752. 
Xiong, H-B. ve Fang. P. (2014), 'Authentic Leadership, Collective Efficacy, and Group Performance: An Empirical Study in China', Social Behavior and Personality, 42(6), ss.921-932

Ye, S. Yu, L. ve Li, K-K. (2012), 'A Cross-Lagged Model of Self-Esteem and Life Satisfaction: Gender Differences among Chinese University Students', Personality and Individual Differences, 52, ss.546-551.

Yerlisu Lapa, T., Ağyar, E. ve Bahadır, Z. (2012), 'Yaşam Tatmini, Serbest Zaman Motivasyonu, Serbest Zaman Katılımı: Beden Eğitimi ve Spor Öğretmenleri Üzerine Bir İnceleme (Kayseri İli Örneği)' Spormetre Beden Eğitimi ve Spor Bilimleri Dergisi, X (2), ss.53-59

Yeşiltaş, M., Kanten, P. ve Sormaz, Ü. (2013), 'Otantik Liderlik Tarzının Prososyal Hizmet Davranışları Üzerindeki Etkisi: Konaklama İşletmelerine Yönelik Bir Uygulama' İstanbul Üniversitesi İşletme Fakültesi Dergisi, 42 (2), ss. 333-350.

Yetim, Ü. (1991), Kişisel Projelerin Organizasyonu ve Örüntüsü Açısından Yaşam Doyumu, Yayınlanmamış Doktora Tezi, Ege Üniversitesi, Sosyal Bilimler Enstitüsü, İzmir.

Ying, X., Li, H., Jiang, S., Peng, F. ve Lin, Z. (2014), 'Group Laziness: The Effect of Social Loafing on Group performance', Social Behavior and Personality: an International Journal, 42 (3), ss.465-472.

Zhaoa, X. R., Qub, H. ve Ghiselli, R. (2011), 'Examining The Relationship of WorkFamily Conflict to Job and Life Satisfaction: A Case of Hotel Sales Managers', International Journal of Hospitality Management, 30, ss.46-54.

\section{EKLER}

ÖLÇEKLER

1: Kesinlikle Katılmıyorum, '2: Katılmıyorum, 3: Ne Katılıyorum Ne atılmıyorum

4: Katılıyorum, 5: Kesinlikle Katılıyorum

Otantik Liderlik (Walumbwa diğ., 2008)

1.Başkalarıyla ilişkilerimi iyileştirmek için geribildirim isterim. (Özfarkındalık)

2.Çalışanlarıma, kast ettiğim şeyi her zaman açıkça belirtirim. (illişkisel Şeffafık)

3.Girişimci olarak iş değerlerim, eylemlerimle tutarlııı gösterir. (İçsel Etik Anlayışı)

4.Girişimci olarak işe ilişkin temel inançlarımı değiştirecek fikirleri ararım. (Dengeli Bilgi İşleme)

5.Başkalarının gözleyebilmesi için yeteneklerimi doğru olarak ifade ederim. (Özfarkındalık)

6.Girişimci olarak yaptığım hataları kabul ederim. (Illişkisel Şeffaflık)

7. Girişimci olarak karar verirken temel inançlarımdan yararlanırım. (İçsel Etik Anlayışı)

8. Girişimci olarak bir sonuca varmadan önce alternatif bakış açılarını dikkatli bir şekilde dinlerim. (Dengeli Bilgi İşleme)

9.Girişimci olarak kendi güçlü ve zayıf yanlarımın farkında olduğumu belli ederim. (Özfarkındalık)

10.Girişimci olarak başkalarıyla bilgiyi açıkça paylaşırım. (Ilişkisel Şeffafık)

11.Girişimci olarak alışıımışın dışında şeyler yapmak için baskılara direnirim. (İçsel Etik Anlayışı)

12.Girişimci olarak bir karar vermeden önce uygun veriyi objektif bir şekilde analiz ederim. (Dengeli Bilgi Işsleme)

13. Girişimci olarak başkaları üzerinde sahip olduğum etkinin açıkça farkındayım. (Özfarkındalık)

14.Girişimci olarak fikir ve düşüncelerimi başkalarına açıkça ifade ederim (Illişkisel Şeffaflık)

15.Girişimci olarak kendi ahlaki standartlarım eylemlerime yön verir. (İçsel Etik Anlayışı) 
16. Girişimci olarak çalışanları zıt bakış açılarını dile getirmeleri için teşvik ederim. (Dengeli Bilgi Işleme)

Sosyal Tembellik (George, 1992)

17.Yapmam gereken bir işle ilgili sorumluluğumu diğer çalışanlara aktarıım.

18.Şirketimde bir işi yapabilecek başka kişiler mevcutsa, ben o işle ilgili daha az çaba gösteririm.

19.Bir işi yapabilecek başkaları varsa, işleri biraz ağırdan alırım.

20.Grup çalışmalarında işin bana düşen kısmını yerine getiririm.

21.Bir işi yapabilecek başka insanlar varsa, o işle ilgili ben daha az zaman harcarım.

22.Şirketimin başarısı için, diğer çalışanlara göre daha fazla çaba ortaya koyarım.

23.Asıl işimin dışında kalan işlerden mümkün olduğu kadar kaçınııım.

24.Bitirmek üzere olduğum bir iş başkasına devrediliyorsa, o iş üzerinde artık çalışmam.

25.Bir işi yapabilecek durumda olan biri varsa, o işi üstlenmekten kaçınırım.

26.Çalışanların bir sorunu olduğunda, çalışanı sorunu çözebilecek birine yönlendiririm.

27.Ekip çalışmalarında, tek başıma olduğumdan daha verimli olurum.

28. Ekip çalışmalarına kıyasla, tek başıma yürüttüğüm bir çalışmayı daha iyi organize ederim.

29.Ben bir iş üzerinde çalışırken, başka biri de işe ortak olursa, işe yönelik sorumluluğum azalır.

Yaşam Tatmini (Diener diğ., 1985)

30. Hayatımdan memnunum.

31. Hayatımda sahip olmak istediğim herşeye sahibim.

32. Yaşam koşullarım pek çok yönleriyle ideallerimi karşılıyor.

33.Tekrar yaşasaydım hayatımda hiç bir şeyi değiştirmezdim.

34.Yaşam koşullarım mükemmeldir. 